\title{
ПЕДАГОГІЧНЕ ОСМИСЛЕННЯ НЕФОРМАЛЬНОЇ ОСВІТИ ЯК СКЛАДОВОЇ СИСТЕМИ ОСВІТИ ДОРОСЛИХ
}

Стаття присвячена проблемі освіти дорослих в контексті педагогічного осмислення. Структурно-логічний аналіз наукових досліджень щодо освіти дорослих дозволив констатувати їх міждисциплінарний характер $і$ визначити провідні аспекти досліджень: фрілософрський, історико-педагогічний, психологічний, сочіальноосвітній, андрагогічний. Аналіз досліджень американських, європейських та вітчизняних учених дозволив визначити складові системи освіти дорослих, зокрема базову, професійну, додаткову, освіту жінок, громадянську, батьківську, дозвіллєву, освіту вдома, сімейну, освіту «третього» віку, релігійну освіту, навчання на робочому місці тощо. Особливий інтерес викликають дослідження сучасних учених стосовно впровадження інноваційних освітніх технологій у процес навчання дорослих, зокрема, інтерактивних, дистанційних.

Ключові слова: освіта дорослих, формальна освіта, неформальна освіта, освіта впродовж життя, неперервна освіта.

Постановка проблеми. Динамізм світового економічного й суспільного розвитку, процеси глобалізації та інтеграції, перехід до інформаційного суспільства зумовлюють необхідність модернізації системи освіти, методологічною основою якої $\epsilon$ концепція «освіти впродовж життя», що розглядається як важлива й обов'язкова складова соціальної моделі сучасного суспільства, як така, що здатна адекватно відповісти на виклики сучасного суспільства і забезпечити людині професійний та соціальний розвиток впродовж життя. Освіта дорослих $€$ одним із важливих складників системи неперервної освіти. На думку П. Ленгранда, «майбутнє освіти, у цілому, та здатність освіти до оновлення залежать від розвитку освіти дорослих» (Огієнко, 2009; Lengrand, 1970, с. 28).

Аналіз актуальних досліджень. Аналіз численних наукових досліджень засвідчує, що проблемам освіти дорослих присвячені роботи таких науковців, як Д. Антонової, І. Беюл, Л. Ведернікової, С Вершловського, В. Гаргай, В. Давидової, С. Змєйова, Т. Зотової, С. Коваленко, Н. Ничкало, О. Митіної, О. Огіенко, К. Онушкіної, І. Фокіної, О. Хахубія та ін. Науковці впевненні, що «філософія освіти дорослих є основою освітньої практики», тією структурою, що здатна поєднати окремі компоненти освіти дорослих в єдине ціле», виявити взаємозв'язок кількісних та якісних змін.

Для нашого дослідження важливе значення мають дослідження науковців стосовно історико-педагогічного розвитку освіти дорослих у США взагалі та неформальної освіти зокрема, серед яких: Дж. Адамс «Кордони американської культури» (1944), К. ґреттен «У пошуках знань» (1955), 
Г. Стабблфілд «До історії освіти дорослих в Америці» (1988), Г. Стабблфілд та П. Кін (1994), Дж. Кетт «Пошук знань в умовах труднощів» (1994). Проте, на думку С. Хоула, працею, у якій «найбільш ретельно виписано історію освіти дорослих у США» $є$ монографія М. Ноулза «Рух за освіту дорослих у Сполучених Штатах» (1962).

Аналіз наукової літератури засвідчив, що освіта дорослих еволюціонувала з розвитком суспільства, тому має тривалу історію і певні традиції, здебільшого розглядалася як неформальна освіта дорослих, що спрямована на саморозвиток, самовдосконалення дорослої людини, задоволення їі освітніх потреб; механізм розбудови громадянського суспільства.

Структурно-логічний аналіз наукових досліджень щодо освіти дорослих дозволив констатувати їх міждисциплінарний характер і визначити провідні аспекти досліджень: філософський, історикопедагогічний, психологічний, соціально-освітній, андрагогічний.

Хоча предметом досліджень науковців був широкий спектр практичних і теоретичних проблем освіти дорослих, проте питанням проблеми освіти дорослих в контексті педагогічного осмислення не приділялася належна увага.

Мета статті. Звідси, метою нашої стаmmi $є$ дослідити проблему педагогічного осмислення неформальної освіти як складової системи освіти дорослих.

Методи дослідження. Для реалізації мети автором використано такі методи дослідження: конкретно наукові (метод термінологічного аналізу, за допомогою якого розкрито сутність ключових понять даної наукової розвідки; метод структурно-логічного аналізу) та загальнонаукові (порівняння, аналіз, узагальнення, синтез, систематизація).

Виклад основного матеріалу. Головними чинниками інтенсивного розвитку освіти дорослих $\epsilon$ ті соціальні та економічні зміни, що відбуваються в суспільстві. На думку Ш. Мерріема, саме соціокультурний контекст, який поєднує три виміри: демографію, глобалізацію економіки і технології, створює як особливі інтереси і потреби дорослої людини, так і освітні можливості, що їм надаються (Огієнко, 2009; Merriam, 2007).

Статистичні дані засвідчують, що в розвинених країнах світу спостерігається тенденція старіння населення. У 2014 році доля людей похилого віку зросла до 12 \% у порівнянні з $9 \%$ у 1994 році, а до 2050 року очікується її зростання до 21 \% (National Center for Education Statistics). Тому, американські вчені наголошують на необхідності створення інклюзивної освітньої моделі, яка враховувала 6 потреби дорослих людей різного віку. У цьому контексті провідне місце займає неформальна освіта дорослих.

Глобальна економіка розглядається дослідниками як мегатенденція XXI століття, яка «має драматичні імплікації для освіти дорослих (M erriam, 2007$, с. $32 ; 67)$. Це пов'язано як із устарюванням знання та невідповідністю 
компетентності, життєвою необхідністю адекватного використання та здійснення професійної перепідготовки кадрів, з переходом до економіки у сфері послуг, змінами у складі робочої сили, так і з переходом до інформаційного суспільства, досягненнями науково-технічного прогресу, появою нових технологій тощо.

На думку дослідників (M erriam, 2013) відповіддю освіти дорослих на соціокультурний контекст сучасного суспільства $€$ інтеграція та взаємопроникнення формальної та неформальної освіти, що слугує основою розбудови суспільства, що навчається.

Звернення до філософських засад освіти дорослих у США ми знаходимо в роботах таких провідних американських вчених як Т. Брамельд, Дж. Брунер, Г. Даркенвальд, Дж. Дьюї, Дж. Еліс (Elias, 2004), А. Маслоу, С. Мерріем, М. Ноулз, А. Вілсон, та ін.

Привертає увагу виокремлення й осмислення філософських підходів Дж. Елісом та С. Мерріемом (Elias, 2004; Oгієнко, 2009, с. 351), які вплинули на розвиток освіти дорослих: лібералізм, прогресивізм, біхевіоризм, гуманізм, радикалізм, конструктивізм. До них звертається у своїх дослідженнях Н. Бідюк, Н. Горун, О. Огієнко (Огієнко, 2009).

Лібералізм має давні коріння й виходить із того, що оскільки людина $€$ справжнім джерелом поступу в суспільному житті, то необхідно забезпечити ії права та свободи, надання рівного доступу до освіти незалежно від рівня добробуту й соціального стану.

Історичні корені філософії прогресивізму пов'язані з прогресивним політичним рухом у суспільстві та освіті. П̈ї основу складають концепції взаємодії освіти і суспільства, емпіричні теорії освіти, демократизації освіти. Оскільки інтенсивний розвиток освіти дорослих припадає саме на період розквіту прогресивізму у США, то не дивно, що він мав суттєвий вплив. Серед прихильників прогресивізму в освіті дорослих назвемо Е. Ліндемана, Б. Бергевіна, які метою освіти дорослих вважали задоволення освітніх потреб дорослої людини і наполягали, що освіта дорослих повинна бути практикоспрямованою, спиратися на досвід дорослої людини.

На думку Н. Бідюк, сучасний шлях розвитку прогресивної освіти - це шлях їі трансформації в концепції «соціального реконструктивізму», «громадської освіти» і «освіти для виживання», у яких поєднуються ідеї, запозичені з педагогічних, філософських, антропологічних, психологічних і соціологічних теоріях. Відомими прихильниками цих концепцій у педагогіці США стали Т.Брамельд, Дж. Вілер, С. Коген, Л. Меткалф, Д. Олівер, У. Стенлі, Б. Собел, Р. Райт, У. Файнберг, Л. Фішер, Г. Шейн, Р. Шерман та інші.

Біхевіористичний напрям, засновником якого був Джон Уотсон, виник у США на початку XX ст. Базуючись на теорії І. Павлова про умовні рефлекси, його прихильники (Дж. Вотсон, Б. Сніннер, Е. Торндайк, та ін.) 
розглядали особистість як сукупність поведінкових реакцій на стимули зовнішнього середовища. Звідси мета освіти дорослих - модифікація поведінки дорослого, з орієнтацією на зміни в людині.

На відміну від біхевіористів, представники гуманістичного напряму (Дж. Браун, Л. Джонсон, А. Маслоу, М. Ноулз, К. Роджерс та ін.) людину вважають самостійною, активною, відкритою до змін і самоактуалізації особистістю, яка є активним суб'єктом навчального процесу.

На думку О. Огієнко, андрагогіка як наука про освіту дорослих, основні положення якої були обґрунтовані американським ученим М. Ноулзом, є зразком гуманістичного підходу в освіті дорослих, виходячи з якого досліджувалися специфічні особливості дорослої людини як суб'єкта навчального процесу, а саме: усвідомлення дорослої людиною себе як самостійної особистості; наявність життєвого та професійного досвіду, який стає джерелом освіти безпосередньо для неї та їі колег; наявність освітніх потреб, прагнення за допомогою навчання вирішити свої життєво важливі проблеми та досягти конкретних цілей; прагнення до самоосвіти, самовиховання, саморозвитку; прагнення до негайної реалізації набутих знань (Огієнко, 2009, с. 62).

Засновники радикального напряму, ґрунтуючись на теоріях анархізму, марксизму, соціалізму, розглядають освіту взагалі та освіту дорослих зокрема як важливий механізм для досягнення радикальних змін у суспільстві. Це актуалізує соціальну роль неформальної освіти дорослих, оскільки вимагає критичного осмислення та особистої їх участі у цих змінах. Яскравим представником цього філософського напряму $€$ Пауло Фрейре, який вважав, що для більш радикальної трансформації суспільства необхідно ширше залучати верста населення до освіти.

На думку дослідників, відбувається процес «переключення» від попередніх філософій, до нової філософії конструктивізму, основними ідеями якого $є$ теоретичний та концептуальний релятивізм, важливість контексту, критичне мислення та трансформаційне навчання. У філософії конструктивізму людина $€$ унікальною за своїм баченням світу, своїми переконаннями, своїм світоглядом, тому вона здатна конструює своє особисте розуміння навколишньої дійсності.

Хоча до XX століття більшість ідей американської освітньої філософії була запозичена з великих систем чи шкіл філософії, а педагогічні ідеї Я. Коменського, І. Гербарта, Дж. Локка, І. Песталоцці, Ж. Руссо, Ф. Фребеля, Г. Спенсера пронизували американські педагогічні теорії до початку XX століття, під впливом ринкових вимог, сформувалася унікальна філософія прагматизму, що поряд із біхевіоризмом і соціальним конструктивізмом виявилася типовим американським, і яка диктувала весь подальший розвиток філософії освіти в США. 
Підтримку ідеї неперервного навчання дорослих знаходимо в роботах учених XVI-XVIII століть. Ян Амос Коменський вважав, що «якщо для всього людського роду весь світ - це школа, від початку до кінця віків, так і для кожної людини його життя - школа, від колиски до труни; необхідно не тільки сказати разом із Сенекою: «Навчатися в будь-якому віці не пізно», а треба казати: кожен вік призначений для учіння, і одні й ті самі межі відведені людському життю і людській школі.

Наші розвідки переконують, що з XIX столітті розпочинається активне осмислення педагогічного досвіду, його обґрунтування. Ідею неформальної освіти дорослих обґрунтовує у своїх наукових працях французький філософ Ж. Кондорсе. Він наголошував на важливості та необхідності навчання людини до пізньої старості, використовуючи для цього лекторії, бібліотеки, музеї тощо. Реалізувати його ідеї на практиці спромігся Р. Оуен, який у 1816 році відкрив першу вечірню школу для дорослих «Новий інститут для утворення характеру людини». У своїй автобіографічній роботі «Ідучи своїм шляхом: автобіографія двадцяти сіми років» (1874) він обґрунтовує значення освіти для дорослої людини, розкриває сутнісні особливості їх навчання та ретельно описує свої труднощі щодо організації шкіл для дорослих.

У процесі дослідження було з'ясовано, що на розвиток освіти дорослих у США та європейських країнах суттєвий вплив мала філософська концепція Ніколая Фредерика Северина Грундтвіга (1783-1872), його концепція Вищої народної школи. Учений вважав освіту для дорослої людини «пробудженням життя», «поширенням світла», «впливом на душу» (Огієнко, 2009, с. 154), а про вищу народну школу писав, що вона «повинна бути школою для життя..., повинна бути історико-поетичною..., повинна бути світлом для народу..., повинна бути школою-інтернатом для дорослих».

Початок розвитку неформальної освіти на концептуальному рівні пов'язується з міжнародною конференцією у Вільямсбергу (США, 1967), коли було розглянуто питання світової кризи в освіті. Ф. Кумбс застерігав, що відбувається «світова криза освіти, правда, не так ярко виражена, як продовольча чи військова криза, але вона може мати серйозні наслідки». Чинниками світової кризи, на його думку, стали: велика кількість тих, хто бажає вчитися; нестача засобів навчання; консервативність системи освіти; інертність суспільства, байдужість до потреб і проблем освіти.

Отже, ідея освіти дорослих, яка розглядалася в контексті неперервної освіти визначалася як засіб вирішення проблеми «нескінченого в кінцевому, досягнення повноти людського розвитку», як принцип постійного поповнення знань, оскільки «життя, яке постійно рухається, потребує повноти та всебічного розвитку людських здібностей», а для цього необхідно навчання, освіту та просвіту «зробити такою ж інстинктивною потребою, як питатися та кормитися тілу», як важливе завдання педагога - «розвивати в 
учнях здатність і бажання навчатися все життя, як результат освіти «необхідно навчатися у школі, але значно більше необхідно навчатися після закінчення школи, і це друге навчання за своїми наслідками, за своїм впливом на людину і на суспільство невимірно важливіше першого».

У контексті наукового осмислення проблеми освіти дорослих значущими $є$ дослідження психологічної науки, що розкривають специфіку психології навчання дорослих: характеристики дорослої людини як суб'єкту навчання (Е. Торндайк, Е. Еріксон, Ю. Кулюткин та ін.), мотивацію дорослої людини до навчання (П. Джарвіс, А. Мітіна, А. Роджерс та ін.) тощо.

Одними з перших публікацій, у яких обґрунтовувалися здатність, прагнення та інтерес дорослої людини до навчання, були праці Е. Торндайка «Учіння дорослих» (1928),, «Інтереси дорослих» (1935) та робота Г. Соренсона «Здібності дорослих» (1938). Саме їх основні положення поклав в основу своєї теорії множинних інтелектів психолог Г. Гарднер. Ним виокремлено вербальний, візуальний, логіко-математичний, кінестатичний, внутрішньо особистісний, натуралістичний та музичний інтелекти, розвиток яких відбувається впродовж всього життя людини.

У цьому контексті слушними є дослідження американських вчених А. Маслоу та К. Роджерса, які дозволили розглянути процес навчання не як «відповідь на стимул чи задоволення вимог до нового знання», а як процес задоволення внутрішніх «спонукань і поривів» (Rogers, 2010, с. 198.)

Теорія Маслоу дала багато для розуміння того, що лежить в основі інтересів і дій дорослих людей, їх потреб (Рис. 1.).

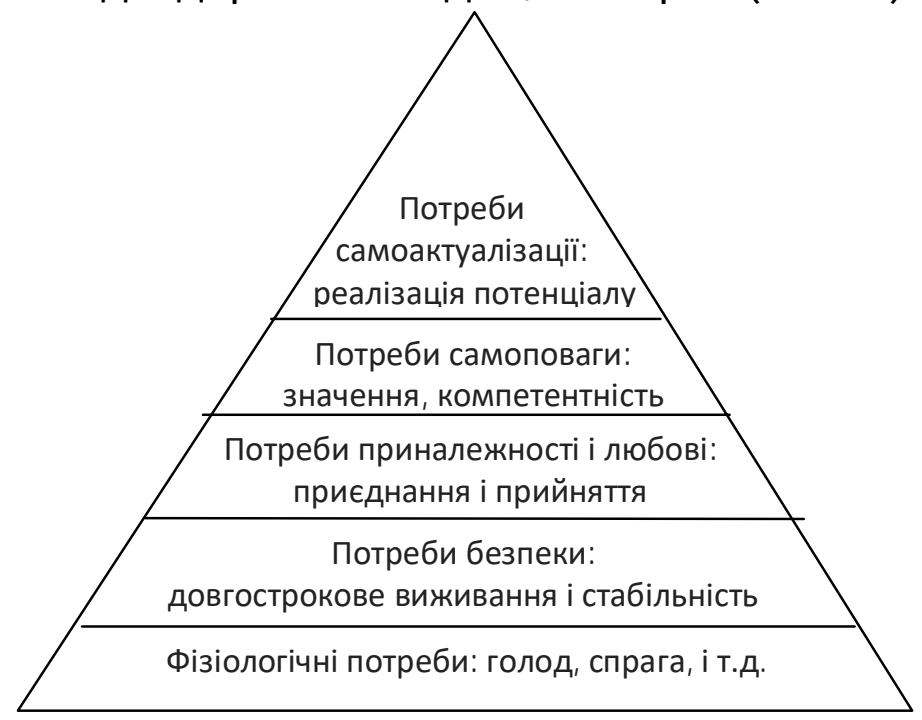

Рис. 1. Ієрархія потреб за А. Маслоу (Maslow, 1970)

Проте А. Маслоу потребу в пізнанні не вніс у свою ієрархію потреб, оскільки вважав, що одні люди мають таку потребу і прагнуть їі задовольнити, а інші мають страх перед знанням.

Водночас П.Джарвіс упевнений, що потреба в пізнанні властива кожній людині, а наявність страху до знання $\epsilon$ не внутрішньою їі 
властивістю, а результатом її негативного соціального досвіду. Без потреби в пізнанні людина не зможе зрозуміти світ, у якому живе, пристосуватися до нього. Тому в його таксономії (учений вважає, що основні потреби доцільніше розглядати у вигляді таксономії) потреби пізнання займають важливе місце (Jarvis, 2012).

Важливим вважаємо висновок М. Ноулза про те, що «дорослі люди не дуже охоче реагують на зовнішню мотивацію в порівнянні 3 внутрішньою» (Knowles, 1970, с. 50).

Наші розвідки переконують, що суттєве значення для розвитку теорії і практики освіти дорослих мали праці психологів Е. Еріксона, Г. Гаулда, Д. Левінсона, Д. Вейланта, у яких виокремлюються основні періоди в житті дорослої людини, аналізуються й визначаються психологічні особливості дорослої людини, що дає можливість більш адекватно вибудовувати процес навчання та визначити специфічні характеристики дорослого як суб'єкту навчання, зокрема такі, як усвідомлення себе самостійною особистістю, наявність багатого життєвого, професійного й соціального досвіду (Staudinger, 2001).

Соціально-освітній аспект дослідження освіти дорослих став предметом дослідження зарубіжних і вітчизняних учених, зокрема, С. Брукфілда, С. Вершловського, Е. Ліндемана, Л. Лук'янової, М. Ноулза, О. Огієнко та ін.

Однією з перших фундаментальних праць була робота Е. Ліндемана «Значення освіти дорослих», яка мала визначальний вплив на усвідомлення значущості розвитку неформальної освіти дорослих. Заслуговують на увагу його підхід до розуміння сутності освіти дорослих. «Освіта - це не тільки підготовка до майбутнього, це - життя, а, тому освіта, як і життя, є нескінченною».

«Освіта не може більше бути обмежена місцем навчання, строком чи кількістю років, освіта повинна дорівнювати навчанню, незалежно від того, де, як чи коли воно відбувається». Така «тріада» освіти (формальна, неформальна і інформальна) була вперше подано в роботі Ф. Кумбса і М. Ахмеда «Криза освіти у сучасному світі».

Аналіз досліджень американських учених Л.Брайсона, С. Брукфіллда, Дж. Даркевольда, П. Джарвіса, Ш. Мерріема (Merriam, 2013) та інших, дозволив визначити складові системи освіти дорослих, зокрема базову, професійну, додаткову, освіту жінок, громадянську, батьківську, дозвіллєву, освіту вдома, сімейну, освіту «третього» віку, релігійну освіту, навчання на робочому місці тощо.

Привертає увагу виокремлення Л. Лук'яновою функцій неформальної освіти дорослих, серед яких: соціальна, яка дає можливість використовувати соціальний досвід і залучати до розв'язання сучасних проблем суспільства; адаптивна як пристосування до нових вимог життя в швидкозмінному світі; регулятивна, що забезпечує регулювання відносин у швидкозмінному 
зовнішньому середовищі; розвивальна, що сприяє оволодінню новими методами, способами дій, збагаченню можливостей людини та їі духовного світу; прогностична - як наукове передбачення особистісного зростання та розвитку громади; компенсуюча - відтворення освітніх можливостей, які раніше були відсутні або втрачені; заохочувальна - стимулювання освітніх потреб людини.

Наші розвідки переконують, що важливою подією в розвиткові теорії і практики освіти дорослих взагалі та неформальної освіти дорослих зокрема мало введення до наукового обігу поняття «андрагогіка». У США цей термін ввів Е. Ліндеман. Він вважав андрагогіку «істинним методом» освіти дорослих (Огієнко, 2009).

Загальновизнаною сьогодні $є$ обґрунтована М. Ноулзом андрагогічна модель навчання дорослих, у якій дорослій людині відводиться провідна роль в організації свого навчання. Основними принципами андрагогічної моделі, що враховують особливості дорослої людини, $\epsilon$ : принцип усвідомленості навчання (дорослим необхідно знати цінність навчання та його користь для них); самоспрямованості (доросла людина $\epsilon$ цілеспрямованою, здатною до самоспрямованого навчання), орієнтації на суб'єктний досвід того, хто навчається, контекстності навчання, актуалізації результатів навчання, умотивованості (Огієнко, 2009).

Вважаємо за доцільне закцентувати на роботах С. Хоула і А. Тафа, у яких доводиться необхідність самоспрямованого навчання дорослих. Ïх ідеї знайшли своє подальше обґрунтування в дослідженнях С. Брукфілда, Р. Брокетта та Р.Хіємстра, Ш. Мерріема, Д. Мезірова та ін. Сьогодні концепція самоспрямованого навчання $€$ визначальною в системі освіти дорослих, оскільки, відповідає прагненню дорослої людини брати на себе відповідальність за своє навчання, прагнення до саморозвитку та самореалізації. «Актуалізація концепції самоспрямованого навчання в освіті дорослих відбиває прагнення зробити їі значущою та активно застосовувати в навчальному процесі дорослої людини».

Для усвідомлення сутності та андрагогічних особливостей процесу навчання дорослих, суттєве значення має теорія навчання американського вченого Р. Ган'є. Він визначає вісім типів навчання, сім із яких складають ієрархію, а восьмий тип може здійснюватися на кожному рівні: сигнальне навчання чи навчання з відповіддю може здійснюватися на будь-якому рівні ієрархії; навчання - стимулювання реакції; моторне навчання - навчання вмінням; вербальне навчання - механічне навчання; навчання відмінностям - формування здатності відрізняти явища; понятійне навчання - навчання концептам; навчання правилам формувати здатність відповідати на сигнали; рішення проблем - вищий рівень ієрархії. 
Особливий інтерес викликають дослідження сучасних учених щодо впровадження інноваційних освітніх технологій у процес навчання дорослих, зокрема інтерактивних, дистанційних (Staudinger, 2011).

Висновки та перспективи подальших досліджень. Аналіз широкого кола вітчизняних і зарубіжних джерел із проблеми освіти дорослих дозволив констатувати їх міждисциплінарний характер, засвідчив, що освіта дорослих $€$ одним із важливих складників системи неперервної освіти. Неперервна освіта розуміється сьогодні не тільки як «учіння довжиною в життя» (lifelong learning), але й як «учіння шириною в життя» (lifewide learning), акцентуючи увагу на розширенні можливостей надання освіти з використанням як формальної, так і неформальної та інформальної освіти. У даному контексті неформальна освіта дорослих розглядається як рівноцінна складова системи освіти дорослих, як соціокультурний компонент, який відображає потребу дорослих людей в одержанні різноманітних освітніх послуг. Тому, для розробки теоретичних засад неформальної освіти важливим є педагогічне осмислення неформальної освіти як складової системи освіти дорослих.

На сучасному етапі розвитку неформальної освіти дорослих в Україні існує багато проблем і запитань, відповіді на більшість із них можна знайти, аналізуючи, систематизуючи й адаптуючи досвід країн, які мають певні досягнення в розвиткові неформальної освіти дорослих, зокрема європейських країн та США.

\section{ЛІТЕРАТУРА}

Огієнко, О.І. (2009). Тенденції розвитку освіти дорослих у скандинавських країнах (друга половина XX століття) (дис. ... д-ра пед. наук: 13.00.01). Київ (Ogienko, O.I. (2009). Tendencies of adult education in Scandinavian countries (second half of the XX century) (DSc thesis). Kyiv).

Elias, J. (2004). Philosophical Foundations of Adult (3rd ed.). NY: Krieger Pub Co.

Jarvis, P. (2012). Adult Learning in the Social Context ( $4^{\text {nd }}$ ed.). London: Routledge.

Knowles, M. (1970). The modern practice of adult education: andragogy versus Pedagogy. New York: Associated Press.

Lengrand, P. (1970). An Introduction to Lifelong Education. Paris: Unesco.

Maslow, A. (1970). M otivation and personality ( $2^{\text {nd }}$ ed.). NY: Harper $\&$ Row.

Merriam, S. (2013). Adult Learning: Linking Theory and Practice. San Francisco: Jossey-Bass.

Merriam, S. (2007). The Profession and Practice of Adult Education: An Introduction. San Francisco: Jossey-Bass.

National Center for Education Statistics (NCES). Retrieved from: http://nces.ed.gov/.

Rogers, A. (2010). Teaching Adults (4th ed.). Buckingham; Philadelphia: Open University Press.

Staudinger, U. (2001). A view on midlife development from life-span theory. Handbook of midlife development, (pp. 3-39). NY: Wiley.

Thompson, M. (2011). Adult Education in a Technological Society. Journal of Lifelong Learning, Vol. 20, 51-71. 


\section{PEЗЮME}

Терехина Наталья. Педагогическое осмысление неформального образования как составляющей системы образования взрослых.

Статья посвящена проблеме образования взрослых в контексте педагогического осмысления. Структурно-логический анализ научных исследований по образованию взрослых позволил констатировать их междисциплинарный характер и определить ведущие аспекты исследований: философский, историкопедагогический, психологический, сочиально-образовательный, андрагогический. Анализ исследований американских, европейских и отечественных ученых позволил определить составляющие системы образования взрослых, в частности базовую, профессиональную, дополнительную, образование женщин, гражданскую, родительскую, досуговых, образование дома, семейную, образование «третьего» возраста, религиозное образование, обучение на рабочем месте и тому подобное. Особый интерес вызывают исследования современных ученых по внедрению инновационных образовательных технологий в процесс обучения взрослых, в частности интерактивных, дистанционных.

Ключевые слова: образование взрослых, формальное образование, неформальное образование, образование в течение жизни, непрерывное образование.

\section{SUM M ARY}

Terokhina Nataliia. The problem of adult education in the context of pedagogical understanding.

The article deals with the problem of adult education in the context of pedagogical thinking. Structural and logical analysis of scientific research of adult education allowed to ascertain their interdisciplinary character and to determine the leading aspects of research: philosophical, historical and pedagogical, psychological, socio-educational, andragogical. It draws attention to the philosophical approaches of scholars who influenced development of adult education: liberalism, progressivism, behaviorism, humanism, radicalism, constructivism.

An important event in the development of theory and practice of adult education, in general, and non-formal adult education, in particular, was introduction to the scientific circulation of the concept of "andragogics".

Today, the concept of self-directed learning is crucial in the adult education system because it responds to the adult's desire to take responsibility for his learning, desire for selfdevelopment and self-realization.

The analysis of studies of American, European and national scientists allowed to determine the components of adult education systems, in particular, basic, professional, additional, women's education, civic, parental, leisure, home education, family, "third age" education, religious education, education at work, etc.

Continuing education is now understood not only as "lifelong learning" but also as "lifewide learning", focusing on expanding of formal, non-formal and informal education. In this context, non-formal adult education is seen as an equivalent component of the adult education system, as a socio-cultural component that reflects the need for adults to receive a variety of educational services. Therefore, for the development of theoretical foundations of non-formal education, it is important to pedagogically understand non-formal education as part of the adult education system. Of particular interest are the studies of modern scholars on the introduction of innovative educational technologies in the process of adult learning, in particular, interactive, distance learning.

Key words adult education, formal education, non-formal education, lifelong learning, continuous education. 